Sustainable Development and Planning X 557

\title{
GEOTOURISM POTENTIAL IN THE CONTEXT OF THE GEOPARK PROJECT FOR THE DEVELOPMENT OF SANTA ELENA PROVINCE, ECUADOR
}

\author{
GRICELDA HERRERA ${ }^{1}$, PAÚL CARRIÓN ${ }^{2}$ \& JOSUÉ BRIONES ${ }^{2}$ \\ ${ }^{1}$ Universidad Estatal Península de Santa Elena, UPSE, Facultad de Ciencias de la Ingeniería, Ecuador \\ ${ }^{2}$ ESPOL Polytechnic University, Escuela Superior Politécnica del Litoral, ESPOL, \\ Centro de Investigaciones y Proyectos Aplicados a las Ciencias de la Tierra (CIPAT), Ecuador
}

\begin{abstract}
The territory of Ancon-Santa Elena stands out for its unique geological diversity which has peculiar characteristics due to the relationships of geodiversity and exuberant biodiversity linked to the marine coastal area. Ancon-Santa Elena is recognized as Cultural Heritage of Ecuador for its great historical value, as it is the place where tar was used in ancient times. In this place, the first Ecuadorian oil well was drilled. Thus, Ancon-Santa Elena is considered an ideal and relevant rural location to carry out a Geopark project due to its uniqueness and aesthetic characteristics. The aim of the research is to analyze the geotourism potential in Ancon-Santa Elena area in Ecuador through the assessment of geosites and industrial sites. Furthermore, the objective is to set up strategies with a Strengths, Weaknesses, Opportunities and Threats (SWOT-TOWS) matrix of the 45 valued sites for local development in the context of the Ancon-Santa Elena Geopark project. Hence, the methodology includes: i) the registration and preliminary inventory of places with outstanding geological and industrial interest in the study area; ii) the preparation of reports and thematic cartographies; iii) quantitative assessment and classification of geosites and industrial sites; iv) development of a SWOT-TOWS matrix which will guarantee the viability of Geotourism as a development pole. The results of the research study are represented through a map using mineral routes as expression of tourism, choosing six relevant sites out of 45 geo- and industrial sites. The researchers focused on a sustainability framework through the preparation of action strategies to ease the compatibility of geodiversity and industrial heritage with current tourism activities. Therefore, this study promotes the conservation and enhancement of the resources in a territory for its sustainable development in rural communities.
\end{abstract}

Keywords: Ancon-Santa Elena Geopark, geotourism, sustainable development.

\section{INTRODUCTION}

Since the Declaration of the Rights of the Memory of the Earth was announced in 1991 in Digne, France [1], progress has been made towards the recognition of the value of geological heritage and geoconservation [2]. Outstanding and unique features of geodiversity within an area constitute a geological heritage which deserves conservation [3].

The concept of geoconservation is closely connected to that of geological heritage, as geoconservation means a series of actions intended to preserve the geological heritage of a place [4]. Both, geoconservation and geological heritage have been understood as new challenges in geological research in the last years of the twentieth century [5].

In many countries, mainly outside Europe, wider knowledge about national geological heritage is limited and incomplete. The development of a geosites inventory should be the first step in any geoconservation strategy. The establishment of conservation and interpretation actions without having a complete geosites inventory is an unsuitable start for any geoconservation project [6]. After the conclusion of a geosites inventory, the geoconservation strategy should proceed with the following stages: geosites characterization, quantification of their relevance, protection according to the national legal framework, geosites conservation, valuation and interpretation and, finally, monitoring [7]. Also, for 
geoconservation, in the 1990s, a new concept was developed by UNESCO, aiming to establish parks focused on the conservation and sustainable use of geological heritage described as the "Geopark" concept [8]. At the beginning of the 21st century, UNESCO promoted the Geoparks project in a Global Geoparks Network [9].

Furthermore, Geoparks have evolved as a new strategy for obtaining sustainable development and further enhancing socio-economic status through the participation of local communities in the continuous geopark activities [10]. Thus, people with different characteristics and purposes (academical, scientific, tourism) visit geoparks and promote geotourism [11], [12].

Geotourism or geological tourism [13] relies on the promotion of nature, especially in the geology and geomorphology of a site [14]. Hence, the areas with a geological structure and varied terrain tend to have greater geotouristic potential [15]. The most important aspect of geotourism is the interpretation of the information of Geological Heritage sites or geosites for every audience [16], [17].

The Ancon-Santa Elena Geopark Project seeks to be a development opportunity for the communities of the province of Santa Elena through resources such as sustainability, the increase of tourist activity and the creation of jobs, aimed at protecting Heritage and the preservation of the territory. Ancon-Santa Elena Geopark, as a territory, includes diverse aspects: i) Aesthetic (unique natural landscape, defined by a coastal profile), ii) Geological (Ancon oil area comprises the sedimentary sequence from the Cretaceous to the Lower Tertiary (Paleocene-Eocene), developed on oceanic crust), iii) Archaeological (superficial pre-Hispanic settlements), iv) Historical and Cultural (San José de Ancon was the place where the first oil well was exploited in Ecuador in 1911) and v) Tourist (located in the "Ruta del Spondylus", important tourist corridor positioning in the domestic and international market).

The aim of this paper is to analyze the potential of geotourism in the Ancon-Santa Elena area in Ecuador by gathering, describing, evaluating and analyzing the sites of geological and industrial interest, for the approach of strategies to ensure the viability of geotourism as a development pole.

\section{GEOGRAPHIC AND GEOLOGICAL SETTINGS}

Fig. 1 illustrates the location of the province of Santa Elena situated west of Ecuador. The province has three counties: Santa Elena, Salinas and La Libertad. Wedged between the south-west flank of the coastal marginal mountain range Chongon-Colonche and the Pacific Ocean. Almost perpendicular to the Andes, the Santa Elena province has a strong influence/dominance of Tertiary and Quaternary detrital, compacted and lithified material, where Cretaceous rocks of marine origin form the core of the province. This axis forms a basin called "Progreso" or "Santa Elena" [18], where we find younger rock material.

\section{METHODOLOGY}

The methodology used in this article is shown schematically in Fig. 2 by i) a flow chart that comprises three phases and combines general starting information, ii) the scientific evaluation following the method of [19] and iii) the integration of geotourism aspects in consideration of a SWOT analysis for the establishment of a TOWS strategy matrix.

\subsection{General starting information}

This information includes the collection and integration of all the references and the projects related to the theme in the analysis area. The classification of this information is relevant 


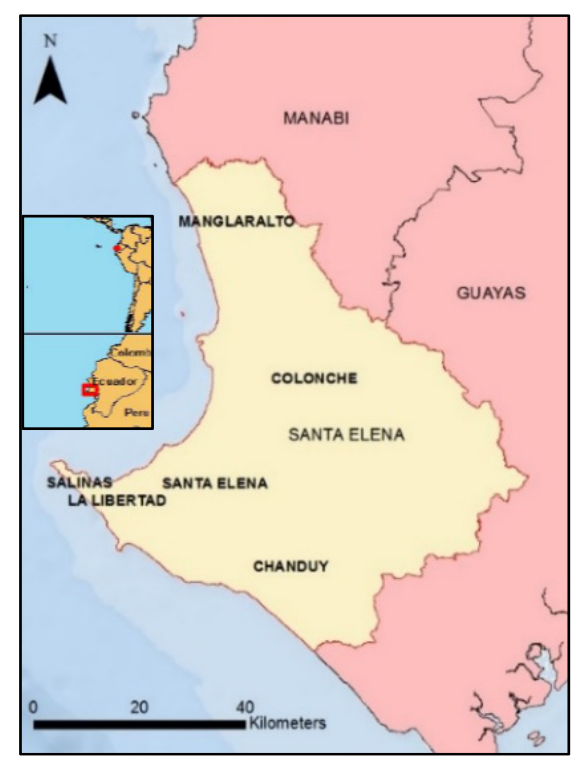

Figure 1: Location of study area.

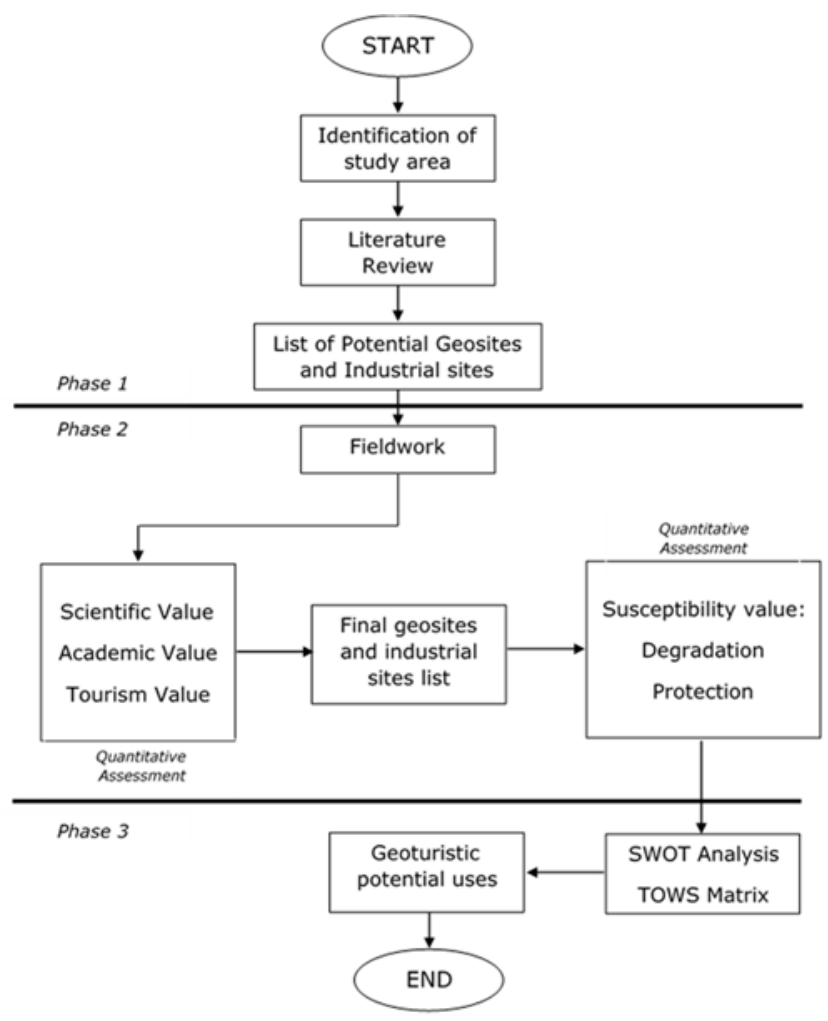

Figure 2: Methodology flowchart. (Source: Adapted from [19].) 
because it allows categorizing sites of geological interest and sites of industrial interest. The inventory of registered sites provides a preliminary idea of the geotouristic study potential. Subsequently, geological reconnaissance-type field trips were carried out for the validation of the sites through the interaction of a broad spectrum of stakeholders such as government delegates, university students and community leaders.

\subsection{Evaluation and classification of geological and industrial sites}

Starting from the inventory made in STAGE I of this methodology, we proceed to the valuation of each site of geological and industrial interest. In this case, three experts who were geological and mining engineers valuated each site. First, the method includes the scientific value, the academic value and the tourist value. In a second section, the environmental degradation is assessed. The third part includes considerations of environmental protection. Tables 1 and 2 illustrate the methodology and rating values.

The three experts made the evaluation of the places of interest, as follows: i) with a score from 0 to 4, each of the parameters given in Tables 1 and 2 are evaluated. This valuation is given by the experience and knowledge of the experts after visiting these places; ii) this rating is multiplied by the weight that has been determined in Tables 1 and 2. With this, the experts obtained a total value for the interest and the degrees of vulnerability, fragility and susceptibility. This susceptibility is determined by the degrees of vulnerability and fragility, as proposed [19]. And, finally, iii) once the experts obtained the interest ratings and susceptibility, they calculated the protection priority according to eqns $1-4$ described below:

$$
\begin{gathered}
P p(S c .)=\left(S c^{2}\right) * S D *\left(1 / 400^{2}\right), \\
P p(A c .)=\left(A c^{2}\right) * S D *\left(1 / 400^{2}\right), \\
P p(T o .)=\left(T o^{2}\right) * S D *\left(1 / 400^{2}\right), \\
P p .=[(S c+A c+T o) / 3]^{2} * S D *\left(1 / 400^{2}\right) .
\end{gathered}
$$

Both in Tables 1 and 2, we obtained an assessment that allows us to know if a site is of interest or susceptible to deterioration and the degree of protection of these. For a better interpretation, classification ranges have been proposed for the given ratings:

- Interest: from 400 to 270 (very high grade), from 269 to 140 (high grade), from 139 to 55 (middle grade) and lower than 55 (low grade).

- $\quad$ Susceptibility (Ds.): From 400 to 225 (very high degree), from 224 to 100 (high grade), from 99 to 50 (medium grade) and less than 50 (low grade).

- Protection priority (Pp.): From 400 to 120 (very high grade), from 119 to 30 (high grade), from 29 to 5 (middle grade) and lower than 5 (low grade).

\subsection{SWOT and TOWS analysis}

Based on the results obtained in stage I and II, a SWOT and TOWS analysis was carried out in the context and approach towards geotourism in this area. As a result of this analysis, we proposed geotouristic development strategies, in accordance with the criteria of society and the potential of the valued sites, leading to the sustainable development of the study area. 
Table 1: Interest ratings (Sc., Ac. and To.) with ranges from minimum 0 to maximum 400. (Source: Adapted from [19].)

\begin{tabular}{|l|l|l|l|}
\hline \multirow{2}{*}{ Parameters } & Interest & \multicolumn{2}{l|}{} \\
\cline { 2 - 4 } & Scientific (Sc.) & Academic (Ac.) & Tourism (To.) \\
\cline { 2 - 4 } & Weight & Weight & Weight \\
\hline Representative & 30 & 5 & 0 \\
\hline Standard or reference site & 10 & 5 & 0 \\
\hline Knowledge of the site & 15 & 5 & 0 \\
\hline conservation status & 10 & 5 & 0 \\
\hline Conditions of observation & 10 & 5 & 5 \\
\hline Scarcity, rarity & 15 & 10 & 0 \\
\hline Geological diversity & 10 & 20 & 0 \\
\hline Educational values & 0 & 15 & 0 \\
\hline Logistics infrastructure & 0 & 5 & 5 \\
\hline Population density & 0 & 15 & 5 \\
\hline $\begin{array}{l}\text { Possibilities for public outreach } \\
\text { (accessibility) }\end{array}$ & 0 & 0 & 10 \\
\hline Size of site & 0 & 5 & 15 \\
\hline Association with other natural elements & 0 & 5 & 5 \\
\hline Beauty & 0 & 0 & 20 \\
\hline Informative value & 0 & 0 & 15 \\
\hline Possibility of recreational activities & 0 & 0 & 5 \\
\hline Proximity to other places of interest & 0 & 0 & 5 \\
\hline Socio-economic situation & 0 & 0 & 10 \\
\hline
\end{tabular}

Table 2: Assessment procedure of Fr., Vul, SD of a site, with ranges of minimum 0 to maximum 400. (Source: Adapted from [19].)

\begin{tabular}{|l|l|l|l|}
\hline \multicolumn{3}{|c|}{ Degradation Susceptibility } \\
\hline Parameters & Fragility (Fr.) & Parameters & Vulnerability (Vu.) \\
\cline { 2 - 4 } & Weight & & Weight \\
\hline Site size & 40 & Proximity to infraestructures & 20 \\
\hline Vulnerability to looting & 30 & Mining exploitation interest & 15 \\
\hline Natural hazards & 30 & Protected area designation & 15 \\
\hline \multirow{2}{*}{} & Indirect protection & 15 \\
\cline { 2 - 3 } & Accesibility & 15 \\
\cline { 2 - 3 } & Ownership status & 10 \\
\cline { 3 - 4 } & Population density & 5 \\
\cline { 3 - 4 } & Proximity to recreational areas & 5 \\
\cline { 3 - 3 } & & \\
\hline
\end{tabular}

\section{RESULTS}

\subsection{List of places of interest}

Through field visits and results with local participation in communities, we made a list of 45 places, 37 sites are of geological interest and 8 are of industrial interest. In the classification of places of geological interest, we entered places like mountains, geologic structures, natural springs, rivers and aquifers; while in places of industrial interest, we included places related to the oil industry, museums and salt industry. In Table 3, we can see the complete list of the 45 places. 
Table 3: List of the 45 places of geological and industrial interest.

\begin{tabular}{|c|c|c|}
\hline No. & Geosites & Characteristic \\
\hline GS1 & Cerro Azúcar & Mountain \\
\hline GS2 & Estructuras sedimentarias San Rafael & Sedimentary structure \\
\hline GS3 & Terrazas Marinas Fm. Tablazo & Marine Terrace \\
\hline GS4 & Fracturas secundarias rellenas de yeso & Filled fractures \\
\hline GS5 & Acantilado Anconcito & Mountain Cliff \\
\hline GS6 & Aguas Termales San Vicente & Natural Spring \\
\hline GS7 & Bad Lands Anconcito & Badlands \\
\hline GS8 & La chocolatera & Geological formation \\
\hline GS9 & Playa de Bolsillo Ayangue & Beach \\
\hline GS10 & Acantilados Ayangue & Mountain Cliff \\
\hline GS11 & Playa Rosada & Beach \\
\hline GS12 & Acuífero Manglaralto & Aquifer \\
\hline GS13 & Cueva de Aguas Profundas El Pelado & Cave \\
\hline GS14 & Islote el Pelado & Islet \\
\hline GS15 & Acantilado Olón & Mountain Cliff \\
\hline GS16 & Vetillas de yeso Puerto Anconcito & Gypsum vents \\
\hline GS17 & Afloramiento Lutitas Chocolate & Basset \\
\hline GS18 & Afloramiento Lutitas Diatomáceas & Basset \\
\hline GS19 & Concreción Calcárea & Concretion \\
\hline GS20 & Cordillera Chongón-Colonche & Mountain Chain \\
\hline GS21 & Afloramiento Areniscas Rojizas & Basset \\
\hline GS22 & Estructuras Sedimentarias Ballenita & Sedimentary structure \\
\hline GS23 & Plataforma abrasión Ballenita & Bench \\
\hline GS24 & Acantilados Ballenita & Mountain Cliff \\
\hline GS25 & Cascada Dos Mangas & Waterfall \\
\hline GS26 & Cordillera Costera Chanduy-Playas & Mountain Chain \\
\hline GS27 & Fuente termal Borbollones & Natural Spring \\
\hline GS28 & Mirador Cerro Capay & Viewer \\
\hline GS29 & Marisma en Santa Paula & Swamp \\
\hline GS30 & Torre El Suspiro & Tower \\
\hline GS31 & Albarradas de Zapotal & Dyke \\
\hline GS32 & Mirador de Montañita & Viewer \\
\hline GS33 & Pozos de agua Manglaralto & Water well \\
\hline GS34 & Tapes en Olón & Dyke \\
\hline GS35 & Acuifero Olón & Aquifer \\
\hline GS36 & Acuifero Valdivia & Aquifer \\
\hline GS37 & Acuifero Río Chico & Aquifer \\
\hline No. & Industrial Sites & Characteristic \\
\hline IS1 & Pozos Artesanales Atahualpa & Water well \\
\hline IS2 & Primer Pozo Petrolero & Oil well \\
\hline IS3 & Mina San Rafael & Mine \\
\hline IS4 & Exudaciones Bituminosas La Libertad & Bituminous exudation \\
\hline IS5 & Exudaciones Bituminosas Anconcito & Bituminous exudation \\
\hline IS6 & Exudaciones bituminosas Santa Paula & Bituminous exudation \\
\hline IS7 & Salinas de San Pablo & Saline Company \\
\hline IS8 & Museo Megaterio & Museum \\
\hline
\end{tabular}




\subsection{Evaluation and classification of geological and industrial sites}

In this stage II, we proceeded with the evaluation of each of the sites of interest given in Table 3, regarding the methodology previously described.

According to the parameters and weights of Table 1, plus the valuation of each one of the experts regarding the interest, as the range of values explained above, the following results are obtained:

- Seven places are classified as very high grade, representing $16 \%$ of the total. Divided into 6 geological and 1 industrial.

- Thirty-four places are classified as high grade, representing $75 \%$ of the total. Divided into 27 geological and 7 industrial.

- $\quad$ Four places are classified as middle grade, representing $9 \%$ of the total. All of them are classified as geological.

In addition, we evaluated the 45 sites of interest for their susceptibility to degradation, as proposed in Table 2. According to the qualification of the experts and the range of values, explained in the methodology, the results are:

- One place is classified as very high Ds., representing 3\% of the total. This is classified as geological.

- Twenty-one places are classified as high Ds., representing $47 \%$ of the total. Divided into 17 geological and 4 industrial.

- Seventeen places are classified as middle Ds., representing $38 \%$ of the total. Divided into 13 geological and 4 industrial.

- Six places are classified as low Ds., representing $12 \%$ of the total. All of them are classified as geological.

Finally, we have the protection priority evaluation, calculated with eqns $1-4$ of the methodology. According to the classification range for Pp., the results are:

- Twenty places are classified with a high degree, representing $44 \%$ of the total. Divided into 16 geological and 4 industrial.

- Twenty-three places are classified with medium grade, representing $52 \%$ of the total. Divided into 20 geological and 3 industrials.

- Two places are classified with low grade, representing $4 \%$ of the total. Divided into 1 geological and 1 industrial.

In Table 4, we observed the evaluation and results of each of the geological and industrial sites according to their interest, susceptibility and protection priority.

\subsection{SWOT and TOWS analysis}

With the registration and assessment of the geological sites and industrial sites, a SWOT analysis was carried out (Table 5) in order to determine the strengths, opportunities, weaknesses and threats presented in the study area. We considered the local development approach through the places of interest in the context of Geotourism. With previous analysis, we developed strategies using a TOWS matrix (Table 6). 
Table 4: Evaluation of geological and industrial sites, according to their interest, susceptibility and protection priority.

\begin{tabular}{|c|c|c|c|c|c|c|c|c|c|c|c|c|c|}
\hline & \multicolumn{4}{|c|}{ Interest } & & \multicolumn{3}{|c|}{ Degradation } & & \multicolumn{4}{|c|}{ Protection } \\
\hline & Sc. & Ac. & To. & Av. & & Fr. & Vul. & Ds & & $\begin{array}{l}\text { Pp. } \\
\text { (Sc.) }\end{array}$ & $\begin{array}{l}\text { Pp. } \\
\text { (Ac.) }\end{array}$ & $\begin{array}{l}\text { Pp. } \\
\text { (To.) }\end{array}$ & $\begin{array}{c}\text { Total } \\
\text { Pp. }\end{array}$ \\
\hline GS3 & 305 & 300 & 310 & 305 & GS2 & 320 & 310 & 248 & GS12 & 102 & 83 & 89 & 91 \\
\hline GS5 & 330 & 265 & 315 & 303 & IS7 & 260 & 320 & 208 & IS5 & 83 & 43 & 110 & 76 \\
\hline GS12 & 320 & 290 & 300 & 303 & IS5 & 280 & 290 & 203 & GS5 & 90 & 58 & 82 & 76 \\
\hline GS7 & 305 & 300 & 300 & 302 & GS21 & 280 & 250 & 175 & GS3 & 76 & 73 & 78 & 76 \\
\hline GS23 & 320 & 240 & 280 & 280 & GS10 & 290 & 240 & 174 & GS21 & 80 & 63 & 74 & 72 \\
\hline IS8 & 280 & 300 & 256 & 279 & GS4 & 260 & 255 & 166 & GS16 & 95 & 69 & 44 & 68 \\
\hline GS16 & 330 & 280 & 225 & 278 & GS12 & 270 & 235 & 159 & GS8 & 61 & 63 & 79 & $\begin{array}{ll}68 \\
\end{array}$ \\
\hline GS8 & 250 & 255 & 285 & 263 & GS8 & 260 & 240 & 156 & GS7 & 62 & 60 & 60 & 61 \\
\hline GS22 & 285 & 210 & 280 & 258 & IS1 & 260 & 220 & 143 & GS2 & 86 & 53 & 47 & 61 \\
\hline GS21 & 270 & 240 & 260 & 257 & GS16 & 200 & 280 & 140 & GS23 & 75 & 42 & 57 & 57 \\
\hline GS24 & 270 & 205 & 295 & 257 & GS5 & 170 & 310 & 132 & IS7 & 42 & 49 & 69 & 53 \\
\hline GS6 & 260 & 255 & 250 & 255 & GS32 & 200 & 260 & 130 & GS24 & 56 & 32 & 67 & 51 \\
\hline GS17 & 270 & 200 & 280 & 250 & GS3 & 260 & 200 & 130 & GS6 & 52 & 50 & 48 & $\begin{array}{l}50 \\
\end{array}$ \\
\hline GS34 & 264 & 236 & 236 & 245 & GS15 & 190 & 270 & 128 & IS1 & 38 & 47 & 56 & 47 \\
\hline IS5 & 255 & 185 & 295 & 245 & GS31 & 200 & 250 & 125 & GS4 & 57 & 35 & 41 & 44 \\
\hline GS14 & 215 & 225 & 290 & 243 & GS6 & 220 & 225 & 124 & GS17 & 51 & 28 & 55 & 44 \\
\hline IS2 & 290 & 205 & 230 & 242 & GS24 & 190 & 260 & 124 & IS2 & 62 & 31 & 39 & 43 \\
\hline GS20 & 265 & 230 & 225 & 240 & IS2 & 160 & 295 & 118 & GS15 & 26 & 34 & 72 & 42 \\
\hline GS26 & 256 & 224 & 240 & 240 & GS23 & 170 & 275 & 117 & GS22 & 43 & 23 & 41 & 35 \\
\hline GS13 & 285 & 240 & 190 & 238 & GS17 & 140 & 320 & 112 & GS10 & 23 & 28 & 46 & 31 \\
\hline GS18 & 220 & 255 & 235 & 237 & GS33 & 200 & 215 & 108 & GS27 & 33 & 25 & 29 & 29 \\
\hline IS1 & 205 & 230 & 250 & 228 & GS7 & 260 & 165 & $\mathbf{1 0 7}$ & IS4 & 34 & 26 & 27 & 29 \\
\hline GS15 & 180 & 205 & 300 & 228 & \begin{tabular}{|l|} 
IS4 \\
\end{tabular} & 230 & 170 & 98 & GS20 & 34 & 26 & 25 & 28 \\
\hline GS11 & 220 & 205 & 250 & 225 & GS34 & 200 & 195 & 98 & GS29 & 29 & 22 & 22 & 25 \\
\hline IS4 & 235 & 205 & 210 & 217 & GS35 & 200 & 195 & 98 & GS32 & 35 & 22 & 18 & 24 \\
\hline GS9 & 220 & 175 & 245 & 213 & GS29 & 170 & 220 & 94 & GS31 & 42 & 20 & 14 & 24 \\
\hline GS33 & 224 & 204 & 204 & 211 & IS3 & 100 & 350 & 88 & GS28 & 27 & 23 & 23 & 24 \\
\hline $\begin{array}{ll}\text { GS4 } \\
\end{array}$ & 235 & 185 & 200 & 207 & GS28 & 170 & 205 & 87 & GS18 & 20 & 26 & 22 & 23 \\
\hline GS35 & 224 & 196 & 196 & 205 & GS22 & 130 & 260 & 85 & GS25 & 22 & 25 & 18 & 22 \\
\hline IS7 & 180 & 195 & 230 & 202 & IS6 & 170 & 195 & 83 & IS3 & 21 & 20 & 24 & 22 \\
\hline GS1 & 240 & 165 & 195 & 200 & GS27 & 260 & 125 & 81 & GS9 & 21 & 13 & 26 & 20 \\
\hline GS2 & 235 & 185 & 175 & 198 & GS36 & 160 & 195 & 78 & GS33 & 33 & 16 & 14 & 20 \\
\hline IS3 & 195 & 190 & 210 & 198 & GS37 & 160 & 195 & 78 & GS13 & 24 & 17 & 11 & 17 \\
\hline GS25 & 200 & 172 & 188 & 187 & GS20 & 230 & 135 & 78 & GS14 & 12 & 13 & 22 & 16 \\
\hline IS6 & 232 & 160 & 136 & 176 & GS19 & 100 & 295 & 74 & GS34 & 22 & 11 & 16 & 16 \\
\hline GS31 & 208 & 164 & 148 & 173 & GS9 & 100 & 280 & 70 & GS11 & 14 & 12 & 18 & 14 \\
\hline GS27 & 220 & 152 & 144 & 172 & GS18 & 100 & 260 & 65 & GS26 & 16 & 13 & 13 & 14 \\
\hline GS10 & 145 & 160 & 205 & 170 & IS8 & 220 & 115 & 63 & GS30 & 15 & 11 & 14 & 13 \\
\hline GS19 & 115 & 160 & 210 & 162 & GS30 & 190 & 130 & 62 & GS35 & 8 & 12 & 17 & 12 \\
\hline GS36 & 188 & 132 & 160 & 160 & GS13 & 110 & 170 & 47 & GS19 & 6 & 12 & 20 & 12 \\
\hline GS32 & 116 & 140 & 168 & 141 & GS11 & 130 & 140 & 46 & GS36 & 8 & 10 & 9 & 9 \\
\hline GS29 & 132 & 144 & 136 & 137 & GS25 & 170 & 105 & 45 & GS37 & 10 & 7 & 9 & 9 \\
\hline GS37 & 140 & 124 & 136 & 133 & GS14 & 200 & 85 & 43 & IS6 & 8 & 7 & 11 & 9 \\
\hline GS28 & 124 & 120 & 144 & 129 & GS26 & 120 & 125 & 38 & IS8 & 4 & 4 & 4 & 4 \\
\hline GS30 & 104 & 100 & 100 & 101 & GS1 & 60 & 40 & 6 & GS1 & 2 & 1 & 1 & 2 \\
\hline
\end{tabular}


Table 5: Study area SWOT analysis.

\begin{tabular}{|c|c|}
\hline Strengths & pportunities \\
\hline $\begin{array}{l}\text { 1. The population of Ancon-Santa Elena are } \\
\text { considered guardians of their territory. } \\
\text { 2. The sites of Geological and Industrial } \\
\text { interest are accessible and with disclosure. } \\
\text { 3. Great natural, cultural and historical wealth. } \\
\text { 4. Conducting joint projects with the } \\
\text { community for its strength and } \\
\text { development. } \\
\text { 5. Stands out for its history, being the place } \\
\text { where the first oil well was drilled in } \\
\text { Ecuador. } \\
\text { 6. Ancestral knowledge for community growth } \\
\text { and preservation of resources. } \\
\text { 7. Ancon-Santa Elena has marine and coastal } \\
\text { ecosystems that are home to biodiversity of } \\
\text { fauna and flora. }\end{array}$ & $\begin{array}{l}\text { a) Development of sustainability projects with } \\
\text { use of ancestral knowledge. } \\
\text { b) Improvement of tourism. } \\
\text { c) Public and private use initiatives. } \\
\text { d) Protection of suitable areas for field studies, } \\
\text { projects and thesis. } \\
\text { e) Base projects as Ancon-Santa Elena } \\
\text { Geopark. } \\
\text { f) Through the Geopark project, employment } \\
\text { sources are created. } \\
\text { g) Projects of government agencies for } \\
\text { reforestation, soil recovery and improve } \\
\text { environmental system. } \\
\text { h) The archaeological resources in the area } \\
\text { linking the community with its history. }\end{array}$ \\
\hline Weak & 8 \\
\hline $\begin{array}{l}\text { 1. Little cohesion between intergovernmental } \\
\text { entities. } \\
\text { 2. Lack of links with universities to develop } \\
\text { projects with communities with lack of } \\
\text { support. } \\
\text { 3. Scarce economic support from government } \\
\text { entities } \\
\text { 4. The population of Ancon-Santa Elena has a } \\
\text { high level of poverty, and there is a shortage } \\
\text { of water. } \\
\text { 5. In some communities are losing traditions } \\
\text { and ancestral knowledge. }\end{array}$ & $\begin{array}{l}\text { a) Lack of protection of assets against } \\
\text { destroyers of these. } \\
\text { b) Pollution and damage to these places due to } \\
\text { poor care and poor treatment by the } \\
\text { community and tourists. } \\
\text { c) Lack of attention by regional authorities. } \\
\text { d) Non-conformity of social groups due to the } \\
\text { inability to solve dairy problems. } \\
\text { e) Problems due to natural threats. } \\
\text { f) High level of vulnerability due to } \\
\text { geodynamic risks. }\end{array}$ \\
\hline
\end{tabular}

Table 6: Development of the TOWS Matrix.

\begin{tabular}{|c|c|}
\hline ns and ope & trategies: weaknesses and opportunities \\
\hline $\begin{array}{l}\text { 1.a. Development of the area through the } \\
\text { promotion and promulgation of } \\
\text { knowledge and ancestral knowledge. } \\
\text { 5.a.b. Development of tourist routes including } \\
\text { proposed places of interest. } \\
\text { 7.c.e. Promulgation and disclosure for the } \\
\text { acceptance of the Ancon-Santa Elena } \\
\text { Geopark. }\end{array}$ & $\begin{array}{l}\text { 2.a.d. Linkage with universities and the } \\
\text { productive sector for joint projects with } \\
\text { society. } \\
\text { 4.b.e. Creation of committees / associations, } \\
\text { with multi-institutional participation for } \\
\text { the declaration as Cultural Heritage / } \\
\text { Geopark. } \\
\text { 5.a.h. Recovery of ancestral knowledge by } \\
\text { communes and communities. }\end{array}$ \\
\hline Strategies & Strategies: $\mathbf{w}$ \\
\hline $\begin{array}{l}\text { 4.a.c.e. Dissemination of projects with } \\
\text { university-community links through } \\
\text { scientific knowledge and ancestral } \\
\text { knowledge. } \\
\text { 5.b.e.f. Create focus groups, between the } \\
\text { community and public authorities, } \\
\text { through multiple participation for the } \\
\text { management of these interest places. }\end{array}$ & $\begin{array}{l}\text { 1.a.c. Plans for the conservation of the heritage } \\
\text { of the Ancon-Santa Elena sector, to be } \\
\text { an icon of national and international } \\
\text { tourist interest. } \\
\text { 4.d.g. Promotion of projects by government } \\
\text { entities with cooperation from the } \\
\text { community to strengthen ties and } \\
\text { socialize them. }\end{array}$ \\
\hline
\end{tabular}


The SWOT analysis and the TOWS matrix generated a series of strategies to address appropriate actions for the preservation, restoration and dissemination of these areas. Finally, we established the basis for recognition of the Ancon-Santa Elena Geopark.

As a result, from the data obtained in Tables 5 and 6 , we obtained the strategies for the development of the existing geodiversity in this area of study:

1. Raise awareness and promote geotourism routes as a basis for a tourist alternative. The stakeholders responsible for its development and application should be local public bodies, educational centers (colleges) and private companies linked to tourism promotion.

2. Propose projects and research with active participation of the community through knowledge and ancestral knowledge. The projects aim is the protection and conservation of the resources of the study area and prevention of risks due to natural threats and geodynamic factors.

3. Guarantee the conservation and defense of geoheritage and geodiversity through the incorporation of land management plans. The elaboration of local norms of behavior of the natural space in general and of the geological-industrial resources in particular is fundamental.

\subsection{Geotourism route proposal}

We proposed a geotouristic route (Fig. 3) as part of the context of one of the strategies outlined above. This georoute integrates some of the places chosen from Table 3 . The following criteria were: i) accessibility to each of the geological sites and industrial sites selected by motorized vehicle; ii) the distance between the places of interest is short, pleasant and attractive circuit and iii) the chosen places are currently preserved by the same community or by a governmental entity. These factors will guarantee a great geodiversity all around.

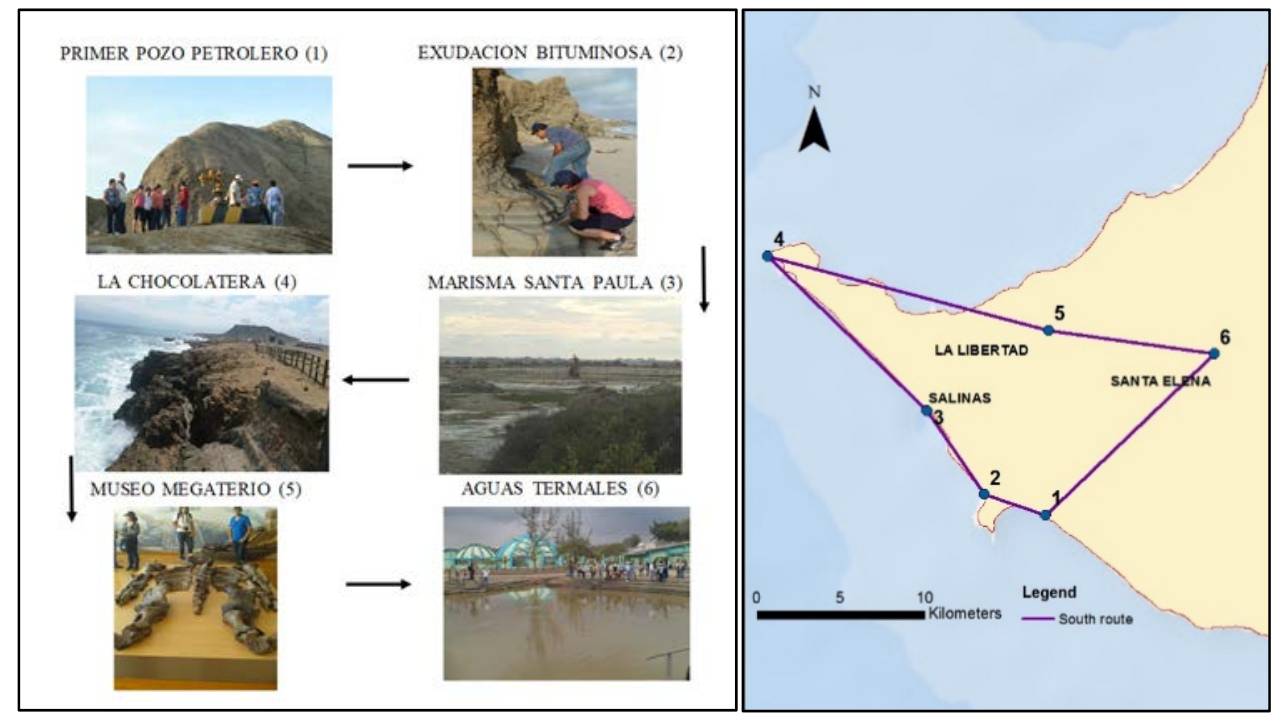

Figure 3: Suggested itinerary, selecting several geological sites and industrial sites. 


\section{DISCUSSION}

From the methodological point of view, the inventory and valuation of applied geosites and industrial sites [19] allowed to assign a semi-quantitative value to the resources and possibilities of the Santa Elena Peninsula, within the context of the Ancon-Santa Elena Geopark. In particular, this process allowed identifying and ordering the areas of interest from three aspects: Interest, Susceptibility and Protection. For the assessment of the industrial sites, we used the same geological places sequence taking into consideration that the areas of industrial interest are a consequence of the use of geological resources.

The valuation of these places facilitated the practical adoption of the inventory by the potential users. The purpose of the evaluation was: i) to guide non-experts on the relative value of a place compared to others that are part of the inventory in the region under consideration. Thus, it allowed prioritizing further use or conservation actions and ii) to highlight a distinguishable set of places with very high and high values.

The SWOT analysis applied allowed relating the potential use of the zones of interest for geotourism. In addition, the application of the TOWS matrix provided important information on the viability of the geotouristic development and the awareness of the full potential of the study area.

Therefore, the assessment of the geological sites and industrial sites show: i) the relevance of the places and ii) the proximity among the areas. An alternative to take advantage of the existence and importance of geological sites and industrial sites may be the recognition of the Ancon-Santa Elena Geopark. Another alternative is the creation of a Geotourism Route that connects the evaluated areas.

\section{CONCLUSIONS}

This research shows the existence of various geosites and industrial interest places in the Santa Elena Peninsula, within the context of the Geopark Ancon-Santa Elena project, which has a potential for exploitation as a geotourism option. From the list of places of interest, we defined 37 geological sites and 8 industrial sites based on the methodology [19], already tested in other studies. The methodology considers three aspects: interest, degradation and conservation or protection. It ensures the development of education, tourism and geoconservation around these sites. The experts evaluated the sites with the specific criteria described in the analysis. In addition, we established the SWOT matrix that provides a comprehensive analysis for the local development considerations of these places.

The inventory and evaluation of the areas of interest in the study area are the basis for an economic initiative and future protection. Moreover, this is the first step to propose development alternatives based on geological and industrial wealth. The creation of a Geotouristic Route, the acceptance of the Ancon-Santa Elena Geopark or type of recognition based on the existing places would favor the geodiversity and the community of the area. Furthermore, the assessment added value to the zone. Consequently, it is possible to take adequate measures for the protection and disclosure of the different resources. Finally, the proposed strategies intend to encourage tourists to visit the area and recommend exclusive programs for children, young people, adults and people with special abilities. Social media and main national media could be in charge of the advertisement of these geosites.

\section{ACKNOWLEDGEMENTS}

We acknowledge the Ancon-Santa Elena Geopark Project and Geoheritage \& Geodiversity Project, in Ecuador, and the collaboration of Cristian Sanchez as a researcher. We express our recognition to the professors Edison Navarrete, Fernando Morante and Josep Mata for their collaboration in the assessment of the sites. 


\section{REFERENCES}

[1] Martini, G. \& Pagès, J. (eds), Actes du premier symposium international sur la protection du patrimoine géologique. Societe Geologique de France, Digne les Bains, pp. 1-266, 1991.

[2] Fassoulas, C., Mouriki, D., Dimitriou-Nikolakis, P. \& Iliopoulos, G., Quantitative assessment of geotopes as an effective tool for geoheritage management. Geoheritage, 4(2), pp. 177-193, 2012.

[3] Gray, M., Geodiversity: The origin and evolution of a paradigm. Geological Society London, 300(1), pp. 31-36, 2008.

[4] Brocx, M. \& Semeniuk, V., Geoheritage and geoconservation: history, definition, scope and scale. Journal of the Royal Society of Western Australia, 90(2), pp. 53-87, 2007.

[5] Gray, M., Valuing and conserving abiotic nature. Journal of Quaternary Science, 19(8), pp. 3-15, 2004.

[6] De Lima, F., Brilha, J. \& Salamuni, E., Inventorying geological heritage in large territories: a methodological proposal applied to Brazil. Geoheritage, 2(3-4), pp. 9198, 2010.

[7] Brilha, J., Inventory and Quantitative assessment of geosites and geodiversity sites: a review. Geoheritage, 8(2), pp. 119-134, 2014.

[8] Patzak, M. \& Eder, W., UNESCO Geopark. A new programme - a new UNESCO label. Geologica Balkanica, 28(34), pp. 33-37, 1998.

[9] Members of geoparks, UNESCO. www.unesco.org/new/en/natural-sciences/ environment/earth-sciences/geoparks/members/. Accessed on: 14 May 2018.

[10] Farsani, N.T., Coelho, C. \& Costa, C., Geotourism and geoparks as novel strategies for socio-economic development in rural areas. International Journal of Tourism Research, 13(1), pp. 68-81, 2012.p

[11] Palacio, J., Geositios, geomorfositios y geoparques: importancia, situación actual y perspectivas en México. Investigaciones Geográficas, Boletín del Instituto de Geografía, 82(1), pp. 24-37, 2013.

[12] Bujdosó, Z., Dávid, L., Wéber, Z. \& Tenk, A., Utilization of geoheritage in tourism development. Procedia-Social and Behavioral Sciences, 188(1), pp. 316-324, 2015.

[13] Hose, T.A., Geotourism, or can tourist become casual rock hounds? Geology on Your Doorstep, 1(1), pp. 207-228, 1996.

[14] Fung, C.K. \& Jim, C., Unraveling Hong Kong Geopark experience with visitoremployed photography method. Applied Geography, 62(1), pp. 301-313, 2015.

[15] Warowna, J., Zgłobicki, W., Kołodyńska-Gawrysiak, R., Gajek, G., Gawrysiak, L. \& Telecka, M., Geotourist values of loess geoheritage within the planned Geopark Małopolska Vistula River Gap. Quaternary International, 399(1), pp. 46-57, 2015.

[16] Newsome, D., Dowling, R. \& Leung, Y.F., The nature and management of geotourism: A case study of two established iconic geotourism destinations. Tourism Management Perspectives, 2(3), pp. 19-27, 2012.

[17] Poiraud, A., Chevalier, M., Claeyssen, B., Biron, P.E. \& Joly, B., From geoheritage inventory to territorial planning tool in the Vercors massif (French Alps): Contribution of statistical and expert cross approaches. Applied Geography, 71(1), pp. 69-82, 2016.

[18] Baldock, J.W., Geología del Ecuador. Ministerio de Recursos Naturales y Energéticos. Dirección General de Geología y Minas, 1(1), pp. 1-50, 1982.

[19] García-Cortés, A., Carcavilla, L., Díaz-Martínez, E. \& Vegas, J., Inventario de Lugares de Interés Geológico de la Cordillera Ibérica. IGME, Madrid, 1(1), pp. 1-147, 2012. 